\title{
Phenotypically Determined Resistance of Neisseria gonorrhoeae to Normal Human Serum: Environmental Factors in Subcutaneous Chambers in Guinea Pigs
}

\author{
By M. GOLDNER, * C. W. PENN, S. C. SANYAL, $\uparrow$ \\ D. R. VEALE AND H. SMITH \\ Department of Microbiology, University of Birmingham, P.O. Box 363, \\ Birmingham B15 $2 T T$
}

(Received 18 December 1978)

\begin{abstract}
Some gonococci obtained from human urethral exudate or from subcutaneously implanted chambers in guinea pigs show a resistance to killing by human serum which is lost on subculture in vitro after a few generations. The environmental factors which may influence the phenotypic expression of resistance to serum killing were investigated in guinea pig chambers and in chamber fluid in vitro.

The redox potential in chambers before and after infection was lower than that of heart blood but conditions were not anaerobic; $\mathrm{H}_{2} \mathrm{O}_{2}$ increased the redox potential but did not decrease gonococcal serum resistance. The chambers were slightly alkaline before and after infection. When the concentration of glucose (depleted in infected chambers by the abundant polymorphonuclear cells) was restored to excess, the serum resistance of the gonococci was unaffected. Concentrations of free amino acids in chambers changed little during infection. Gonococci adapted to growth in chambers and subsequently rendered serum-sensitive by growing once on agar reverted to serum-resistance after 0.5 to $1 \mathrm{~h}$ incubation in chamber fluid in vitro at $37^{\circ} \mathrm{C}$ but not at $25^{\circ} \mathrm{C}$ or $4{ }^{\circ} \mathrm{C}$. After 16 to $24 \mathrm{~h}$ growth at $37^{\circ} \mathrm{C}$, resistance was again lost. The reversion to serum resistance did not occur in a complex laboratory medium. Examination of the chamber fluid after growth of gonococci in vitro showed depletion of lactate, glutamine and proline.
\end{abstract}

\section{INTRODUCTION}

The environment in vivo affects the production of the determinants of microbial pathogenicity by selection of genotypes and through phenotypic change. Recent studies on gonococcal pathogenicity provide excellent examples of these types of influence. A selective process occurs for organisms resistant to killing by phagocytes whilst phenotypic change underlies their resistance to the bactericidal action of human serum (Penn et al., 1977a).

The loss of resistance to killing by human serum on subculture was first detected in strains of gonococci isolated from urethral pus (Ward et al., 1970). A similar resistance to human serum, maintained by passaging gonococci serially through human serum in vitro, was lost rapidly on subculture on normal solid media (McCutchan et al., 1976). We observed that gonococci adapted to growth in vivo in plastic chambers implanted subcutaneously in guinea pigs were resistant to killing by human serum but became susceptible on subculture

\footnotetext{
* Permanent address: Department of Microbiology and Parasitology, FitzGerald Building, University of Toronto, Toronto M5S 1A1, Canada.

$\dagger$ Permanent address: Department of Microbiology, Institute of Medical Sciences, Banaras Hindu University, Varanasi 221005, India.
} 
in vitro (Penn et al., 1976). These various observations were made on cultures grown for $24 \mathrm{~h}$ or more and the loss of serum resistance may therefore have been due to mutation and selection. However, Rittenberg et al. (1977) showed that the resistance of guinea pig chamber gonococci to human serum was lost after only a few generations in vitro both in culture medium and in chamber fluid. This supports the hypothesis of a phenotypic change resulting from a deficiency of the environment in vitro.

Some strains of gonococci found in urethral pus (Ward et al., 1970), in guinea pig chambers (Penn et al., 1977b) and, notably, in cases of disseminated gonorrhoea (Schoolnik et al., 1976) have a resistance to killing by human serum which is stable to subculture in vitro. However, this paper is concerned only with the type of resistance which is phenotypically controlled and particularly with that expressed in guinea pig chambers. This resistance may well be relevant to the pathogenesis of gonorrhoea since gonococci in urethral pus reacted similarly to those adapted to growth in guinea pig chambers.

Research on the biochemical basis for the phenotypic resistance to killing by human serum would be facilitated by a medium for the production of large numbers of serumresistant gonococci in vitro, and investigations of the environmental factors within the guinea pig chambers might help in the design of such a medium. Previous studies (Rittenberg et al., 1977) have emphasized that after $24 \mathrm{~h}$ growth in vivo the glucose concentration was low $\left(\leqslant 0.5 \mathrm{mmol} \mathrm{l}^{-1}\right)$ and the population was limited to $1 \times 10^{6}$ to $5 \times 10^{6}$ organisms $\mathrm{ml}^{-1}$ in chamber fluid. The concentration of glucose fell dramatically because of usage by cells involved in the inflammatory response which began 5 to $8 \mathrm{~h}$ after infection. With such a striking glucose depletion, it seemed important to monitor environmental factors within the chamber which might influence energy sources utilized by gonococci ( $\mathrm{pH}$, redox potential, lactate, acetate and amino acid concentrations) in an attempt to assess, and subsequently to influence, the limiting conditions which might alter the serum susceptibility of the gonococci. Lactate or acetate may serve as alternative energy sources in certain circumstances (Holten, 1976; Hebeler \& Morse, 1976), as may amino acids, depending on the availability of glucose (Holten, 1973; Hebeler \& Morse, 1976; M. A. Chan \& M. Goldner, personal communication). The changes taking place in the same environmental factors concurrent with the reversion of gonococci from serum sensitivity to resistance when cultured in chamber fluid in vitro were also studied.

\section{METHODS}

Organism. Neisseria gonorrhoeae strain BS4 (a laboratory strain, BS, which had been passaged four times through guinea pig chambers) was used immediately after removal from the animal or after dilution 10- to 20 -fold in cryo-protective medium followed by storage in liquid nitrogen. After one subculture on agar the strain was called BS4 (agar) (Penn et al., 1976).

Implantation of chambers in guinea pigs. The techniques for implanting, inoculating and sampling of chambers were as described by Veale et al. (1975), except that tincture of iodine was used to disinfect the skin before implantation.

Media, cultural and counting procedures. These were as described previously (Veale et al., 1975; Penn et al., 1976, 1977b; Rittenberg et al., 1977). Liquid cultures were grown in 0.5 to $2.0 \mathrm{ml}$ medium contained in loosely capped $7.5 \mathrm{ml}$ Bijou bottles incubated at $37^{\circ} \mathrm{C}$ in candle jars.

Alteration of chamber environment. The redox potential in a chamber was increased by serial injections of $0 \cdot 1 \mathrm{ml} 1 \%(\mathrm{v} / \mathrm{v}) \mathrm{H}_{2} \mathrm{O}_{2}(100 \mathrm{vol}$.), and the glucose concentration was increased by serial injections of $0 \cdot 2 \mathrm{ml}$ glucose $\left(800 \mathrm{mmol}^{-1}\right)$.

Chamber fluid for cultures in vitro. Pooled fluid from at least five chambers (which had been in situ for 6 to 10 weeks) was centrifuged at $1000 \mathrm{~g}$ for $5 \mathrm{~min}$ to remove cells and used either immediately or after storage at $-20^{\circ} \mathrm{C}$ for not more than 2 weeks.

Measurement of resistance to killing by normal human serum. A pool of freshly collected human serum from about 10 subjects was stored in $0.5 \mathrm{ml}$ portions at $-70^{\circ} \mathrm{C}$. It was thawed at room temperature immediately before use, diluted 1 in 4 in barbitone buffer $\mathrm{pH} 7 \cdot 5$ [consisting of ( $\mathrm{mmol}^{-1}$ ): $\mathrm{NaCl}, 150$; sodium barbitone, 1.82 ; barbitone, $\left.3.13 ; \mathrm{MgCl}_{2}, 0.5 ; \mathrm{CaCl}_{2}, 0.15\right]$ and dispensed as duplicate $0.1 \mathrm{ml}$ samples into wells in polystyrene microtitre trays (Flow Laboratories, Scotland). Trypticase Soy Broth (TSB; BBL) was also dispensed in duplicate wells, as controls. The test culture was diluted in TSB to contain about $10^{4}$ colony- 
forming units (c.f.u.) $\mathrm{ml}^{-1}$ and vortex mixed with $3 \mathrm{~mm}$ diam. glass beads for $30 \mathrm{~s}$ to disperse any clumps; then $10 \mu \mathrm{l}$ was added to each well and the contents were mixed by repeated expulsion from the micropipette. After incubation at $37^{\circ} \mathrm{C}$ for $30 \mathrm{~min}$, a $100 \mu \mathrm{l}$ sample from each well was taken for viable count. The count in the experimental sample containing fresh human serum expressed as a percentage of that in the control sample containing TSB was taken as the measure of serum resistance. Control tests showed that survival in TSB was comparable with that in heated $\left(56^{\circ} \mathrm{C}, 30 \mathrm{~min}\right)$ human serum. A culture of a known susceptible strain (BSSH; Penn et al., 1977b) was included in every test to ensure that the serum was active, i.e. that resistance of this strain was less than $20 \%$.

Measurement of redox potential within chambers in vivo. Redox potential was measured with a platinum electrode against a calomel reference electrode. The platinum electrode (wire) was cleaned in chromic acid before use and inserted into the chambers of anaesthetized guinea pigs through fine polypropylene micropipette tips which had been pushed through needle punctures in the overlying skin and connective tissue. A second micropipette tip containing agarose gel saturated with $\mathrm{KCl}$ was also inserted, and a calomel reference electrode (K4112; Radiometer, Copenhagen, Denmark) was connected by contact with the agarose salt bridge in the broad end of the micropipette tip. The potential difference $(\mathrm{mV})$ between electrodes was measured with a $\mathrm{pH} / \mathrm{mV}$ meter (Radiometer PHM 62). The electrode function was checked by immersing the electrodes in a saturated solution of quinhydrone in $0 \cdot 1 \mathrm{M}$-phosphate buffer, $\mathrm{pH} 7 \cdot 0$, which always gave a reading within $\pm 10 \mathrm{mV}$ of the theoretical value of $44 \mathrm{mV}$. Readings obtained were added to the potential of the reference electrode $(244 \mathrm{mV})$ to give values on the hydrogen scale. For comparison, the redox potential of heart blood and of caecal contents of guinea pigs was measured immediately after death by cervical dislocation.

$\mathrm{pH}$ of chamber fluid. Fresh samples $(0.3$ to $0.4 \mathrm{ml})$ of chamber fluid were centrifuged at $1000 \mathrm{~g}$ for $5 \mathrm{~min}$ and then the $\mathrm{pH}$ was measured using a small combination electrode and pH meter (Radiometer PHM 62).

Analysis of chamber fluid. Glucose was determined by the glucose oxidase method of Werner et al. (1970), using the Test-combination Glucose (Boehringer). L(+)-Lactate was determined by the lactate dehydrogenase-NAD ${ }^{+}$method of Gutman \& Wahlefeld (1974), using the Test-combination Lactate (Boehringer). Acetate was determined by gas-liquid chromatography using a Pye series 104 chromatograph (Pye Unicam) with a Tenax AD column, $\mathrm{N}_{2}$ as the carrier gas $\left(30 \mathrm{ml} \mathrm{min}^{-1}\right)$ and a flame ionization detector; all temperatures $125^{\circ} \mathrm{C}$, attenuation $\times 50$, range 0.5 to $9.5 \mathrm{mV}$, sample volume $0.8 \mu \mathrm{l}$. Amino acids were determined on a Locarte autoanalyser (Locarte, London) after removal of protein by the addition of an equal volume of $10 \%$ $(\mathrm{v} / \mathrm{v})$ perchloric acid.

\section{RESULTS}

\section{Redox potential, $\mathrm{pH}$, lactate, acetate and amino acid concentrations in chambers in vivo before and after infection with gonococci}

The redox potentials of five uninfected chambers $(340,310,317,250$ and $349 \mathrm{mV})$ were lower than that of left ventricular heart blood ( $442 \mathrm{mV}$ in one experiment). After infection for $24 \mathrm{~h}$, the redox potentials were decreased to $248,229,263,159$ and $281 \mathrm{mV}$, respectively, but the chambers were not anaerobic. Redox potentials of the caecal contents of two guinea pigs were -76 and $-26 \mathrm{mV}$.

The $\mathrm{pH}$ values of four chambers before infection and $24 \mathrm{~h}$ after infection were, respectively, $7 \cdot 6$ and $7 \cdot 5,7 \cdot 7$ and $7 \cdot 6,7 \cdot 9$ and $7 \cdot 7$, and $8 \cdot 0$ and $7 \cdot 8$.

Glucose, lactate and acetate concentrations in the chambers were followed during infection. As reported previously (Rittenberg et al., 1977), glucose, present initially at 4 to $5 \mathrm{mmol} \mathrm{l}^{-1}$, was reduced to $0.4 \mathrm{mmol}^{-1}$ during the first $24 \mathrm{~h}$. Concurrently, as might be expected from glycolysis in phagocytes, the lactate concentration doubled to about $8 \mathrm{mmol}$ $1^{-1}$ (Fig. 1). The acetate concentration remained almost constant at about $2.5 \mathrm{mmol}^{-1}$. There was little further change in the concentrations of glucose, lactate and acetate up to 10 and $20 \mathrm{~d}$ infection.

Amino acid concentrations were measured in two chambers before and after infection. No marked changes occurred. Asparagine was not found, presumably due to the presence of asparaginase in guinea pig serum (Broome, 1961). 


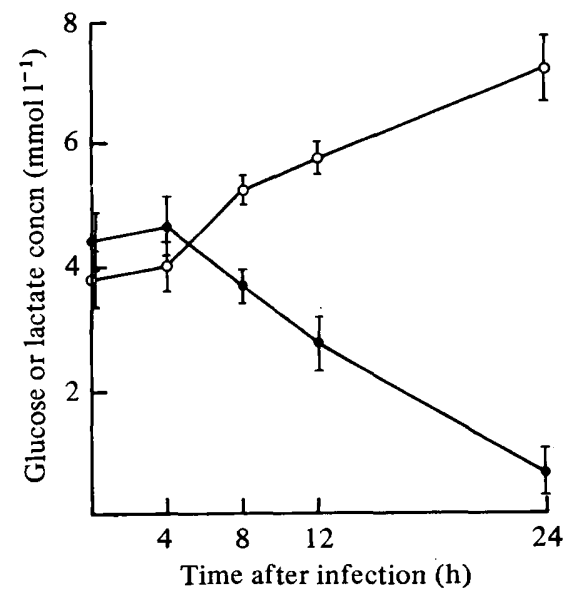

Fig. 1. Changes in the concentrations of glucose $(O)$ and lactate $(O)$ in guinea pig chambers during infection with $N$. gonorrhoeae. The results are the mean of six experiments; the bars indicate the standard error of the mean.

Table 1. Effect of increasing the redox potential within an infected chamber on the viable count and serum resistance of serum-resistant gonococci (BS4) present in the chamber

The results are typical of three similar experiments.

\begin{tabular}{|c|c|c|c|c|}
\hline \multirow[b]{2}{*}{$\begin{array}{l}\text { Time after } \\
\text { infection } \\
\text { (h) }\end{array}$} & \multicolumn{2}{|c|}{ Chamber conditions } & \multicolumn{2}{|c|}{ Gonococci } \\
\hline & $\underset{\text { treated }}{\mathrm{H}_{2} \mathrm{O}_{2}}$ & $\begin{array}{c}\text { Redox } \\
\text { potential } \\
(\mathrm{mV})\end{array}$ & $\begin{array}{l}\text { No. of } \\
\text { c.f.u. } \\
\mathrm{ml}^{-1}\end{array}$ & $\begin{array}{l}\text { Serum } \\
\text { resistance } \\
(\%)\end{array}$ \\
\hline 24 & - & 248 & $5 \times 10^{6}$ & 60 \\
\hline 24 & + & 418 & ND & ND \\
\hline 26 & + & 278 & $7 \times 10^{6}$ & $>90$ \\
\hline 28 & + & 390 & $1 \times 10^{7}$ & $>90$ \\
\hline
\end{tabular}

ND, Not determined.

* Where indicated, $0 \cdot 1 \mathrm{ml} 1 \%(\mathrm{v} / \mathrm{v}) \mathrm{H}_{2} \mathrm{O}_{2}(100$ vol.) was injected at $24 \mathrm{~h}$ and then at $0.5 \mathrm{~h}$ intervals up to $27.5 \mathrm{~h}$.

$\dagger$ Serum resistance was defined as the count after treatment with serum for $30 \mathrm{~min}$ at $37^{\circ} \mathrm{C}$ expressed as a percentage of the count of control organisms in Trypticase Soy Broth at $37^{\circ} \mathrm{C}$.

\section{Serum resistance of gonococci from chambers in which the redox potential or glucose concentration had been artificially increased}

Raising the redox potential in the chamber with $\mathrm{H}_{2} \mathrm{O}_{2}$ did not reduce the resistance to human serum of the gonococci growing in the chamber (Table 1).

The rate of multiplication, the population at $24 \mathrm{~h}$ and the resistance to human serum during that time of gonococci growing in chambers with added glucose were no different from those of organisms growing in normal chambers (Table 2). Similarly, the omission of glucose from AG broth (Veale et al., 1975; Penn et al., 1976; Rittenberg et al., 1977) [apart from the residual amount $\left(1\right.$ to $\left.1.5 \mathrm{mmol}^{-1}\right)$ contributed by the newborn calf serum] did not alter the sensitivity to human serum of BS4 (agar) organisms, i.e. reversion to serum resistance, as occurs when such organisms are cultured in chambers in vivo (Rittenberg et al., 1977), did not take place.

Growth of serum-sensitive BS4 (agar) in chamber fluid in vitro: effect on serum sensitivity of gonococci and chamber fluid composition

Serum-sensitive gonococci BS4 (agar) incubated in chamber fluid in vitro at $37^{\circ} \mathrm{C}$ remained sensitive for 0.5 to $1 \mathrm{~h}$ and then became resistant. At $25^{\circ} \mathrm{C}$ and $4{ }^{\circ} \mathrm{C}$ the organisms 
Table 2. Effect of added glucose on serum resistance of the serum-resistant gonococci (BS4) during their growth in guinea pig chambers

Results are for a typical experiment.

\begin{tabular}{|c|c|c|c|c|c|c|}
\hline \multirow[b]{3}{*}{$\begin{array}{c}\text { Time after } \\
\text { inoculation } \\
\text { of chamber } \\
\text { (h) }\end{array}$} & \multicolumn{3}{|c|}{ Glucose-treated chamber* } & \multicolumn{3}{|c|}{ Normal chamber } \\
\hline & \multirow[b]{2}{*}{$\begin{array}{l}\text { Glucose } \\
\text { concn } \\
\left(\mathrm{mmol} \mathrm{l}^{-1}\right)\end{array}$} & \multicolumn{2}{|c|}{ Gonococci } & \multirow[b]{2}{*}{$\begin{array}{c}\text { Glucose } \\
\text { concn } \\
\left(\mathrm{mmol} \mathrm{l}^{-1}\right)\end{array}$} & \multicolumn{2}{|c|}{ Gonococci } \\
\hline & & $\begin{array}{l}\text { No. of } \\
\text { c.f.u. } \mathrm{ml}^{-1}\end{array}$ & $\begin{array}{l}\text { Serum } \\
\text { resistance } \dagger \\
(\%)\end{array}$ & & $\begin{array}{l}\text { No. of } \\
\text { c.f.u. } \mathrm{ml}^{-1}\end{array}$ & $\begin{array}{l}\text { Serum } \\
\text { resistance } \dagger \\
(\%)\end{array}$ \\
\hline $\begin{array}{l}0 \\
0.75\end{array}$ & $\begin{array}{l}4 \cdot 7 \\
44\end{array}$ & $\begin{array}{l}2.5 \times 10^{3} \\
2.5 \times 10^{3}\end{array}$ & $\begin{array}{l}\mathrm{ND} \\
>90\end{array}$ & $\begin{array}{l}7 \cdot 6 \\
7.9\end{array}$ & $\begin{array}{l}2.5 \times 10^{3} \\
2.5 \times 10^{3}\end{array}$ & $\begin{array}{l}>90 \\
>90\end{array}$ \\
\hline 4 & 21 & $2 \times 10^{4}$ & $>90$ & $4 \cdot 8$ & $2 \times 10^{4}$ & $>90$ \\
\hline 6 & 40 & $8 \times 10^{4}$ & $>90$ & $4 \cdot 6$ & $6 \times 10^{4}$ & $>90$ \\
\hline 12 & $27 \cdot 7$ & $4 \times 10^{5}$ & $>90$ & $3 \cdot 1$ & $2 \times 10^{5}$ & $>90$ \\
\hline 24 & $3 \cdot 3$ & $2 \times 10^{6}$ & $>90$ & $0 \cdot 23$ & $2 \times 10^{6}$ & $>90$ \\
\hline
\end{tabular}

ND, Not determined.

* Glucose $\left(0 \cdot 2 \mathrm{ml}, 800 \mathrm{mmol} \mathrm{l}^{-1}\right)$ was injected at $0,0 \cdot 75,4,6$ and $12 \mathrm{~h}$ after inoculation. Samples for assay of glucose were taken immediately before injection of glucose.

$\dagger$ Expressed as in Table 1.

\section{Table 3. Reversion of serum-sensitive gonococci [BS4 (agar)] to resistance} during incubation in chamber fluid in vitro

Two different batches of chamber fluid were used in these experiments.

Gonococci incubated at:

$\begin{gathered}\text { Length of } \\ \text { incubation } \\ \text { (h) }\end{gathered}$
Experiment
0
$0 \cdot 5$
1
3
24
Experiment
0
$0 \cdot 5$
1
3
24

\begin{tabular}{|c|c|c|c|c|c|}
\hline & & Gonococe & ubated at: & & \\
\hline & & & & 4 & \\
\hline $\begin{array}{l}\text { No. of } \\
\text { c.f.u. } \mathrm{ml}^{-1}\end{array}$ & $\begin{array}{l}\text { Serum } \\
\text { resistance* } \\
(\%)\end{array}$ & $\begin{array}{l}\text { No. of } \\
\text { c.f.u. } \text { ml-1 }^{-1}\end{array}$ & $\begin{array}{l}\text { Serum } \\
\text { resistance* } \\
(\%)\end{array}$ & $\begin{array}{l}\text { No. of } \\
\text { c.f.u. } \mathrm{ml}^{-1}\end{array}$ & $\begin{array}{c}\text { Serum } \\
\text { resistance } \\
(\%)\end{array}$ \\
\hline $2 \times 10^{4}$ & $<5$ & $1 \times 10^{5}$ & $<5$ & $1 \times 10^{5}$ & $<5$ \\
\hline $2 \times 10^{4}$ & $<5$ & $1 \times 10^{5}$ & $<5$ & $4 \times 10^{4}$ & $<5$ \\
\hline $2.5 \times 10^{4}$ & $>90$ & $1 \times 10^{5}$ & $<5$ & $2.5 \times 10^{4}$ & $<5$ \\
\hline $6 \times 10^{4}$ & $>90$ & $1 \times 10^{5}$ & $<5$ & $1 \times 10^{4}$ & $<5$ \\
\hline $3 \times 10^{7}$ & $<5$ & ND & ND & ND & ND \\
\hline $1 \times 10^{4}$ & $<5$ & $1 \times 10^{5}$ & $<5$ & $1 \times 10^{5}$ & $<5$ \\
\hline $1 \times 10^{4}$ & $<5$ & $1 \times 10^{5}$ & $<5$ & $1 \times 10^{5}$ & $<5$ \\
\hline $1 \times 10^{4}$ & $>90$ & $1 \times 10^{5}$ & $<5$ & $5 \times 10^{4}$ & $<5$ \\
\hline $3.5 \times 10^{4}$ & $>90$ & $1 \times 10^{5}$ & $<5$ & $1 \times 10^{4}$ & $<5$ \\
\hline $8 \times 10^{6}$ & $<5$ & ND & ND & ND & ND \\
\hline
\end{tabular}

ND, Not determined.

* Expressed as in Table 1.

remained sensitive for at least $3 \mathrm{~h}$ (Table 3). Although the number of c.f.u. inoculated was 10 -fold greater at $25^{\circ} \mathrm{C}$ and $4{ }^{\circ} \mathrm{C}$ than at $37^{\circ} \mathrm{C}$, to allow for a decline in numbers during the course of the experiments, this was not the reason for the lack of reversion to resistance at the lower temperatures, since in another experiment an inoculum of equal magnitude incubated at $37^{\circ} \mathrm{C}$ reverted just as rapidly as did the smaller ones.

In further experiments, observations at between 12 and $24 \mathrm{~h}$ revealed that reversion to serum sensitivity occurred when the number of c.f.u. $\mathrm{ml}^{-1}$ had increased by $10^{3}$, i.e. after 10 generations. The time taken for this increase ranged from 16 to $24 \mathrm{~h}$. Organisms grown at $37{ }^{\circ} \mathrm{C}$ in AG broth (Rittenberg et al., 1977) did not show a similar temporary reversion to resistance.

In marked contrast to chamber fluid in vivo, there was only a small decrease ( 0 to $30 \%$ ) in 
Table 4. Changes in concentrations of glucose, lactate, alanine, aspartate, glutamine and proline in chamber fluid in vitro after growth of serum-sensitive gonococci [BS4 (agar)]

The results are typical of three similar experiments with different batches of chamber fluid.

\begin{tabular}{|c|c|c|c|}
\hline \multirow[b]{2}{*}{ Component } & \multicolumn{3}{|c|}{ Concn $\left(\mathrm{mmol} \mathrm{l}^{-1}\right)$ in chamber fluid: } \\
\hline & Initially & $\begin{array}{l}\text { After } 24 \mathrm{~h} \\
\text { at } 37^{\circ} \mathrm{C} \\
\text { (control) }\end{array}$ & $\begin{array}{l}\text { After } 24 \mathrm{~h} \\
\text { growth of } \\
\text { BS4 (agar)* }\end{array}$ \\
\hline $\begin{array}{l}\text { Glucose } \\
\text { Lactate }\end{array}$ & $\begin{array}{l}4 \cdot 50 \\
5 \cdot 92\end{array}$ & $\begin{array}{l}5 \cdot 04 \\
6 \cdot 22\end{array}$ & $\begin{array}{l}3.06 \\
0.1\end{array}$ \\
\hline $\begin{array}{l}\text { Alanine } \\
\text { Aspartate } \\
\text { Glutamine } \\
\text { Proline }\end{array}$ & $\begin{array}{l}0.31 \\
0.02 \\
0.41 \\
0.34\end{array}$ & $\begin{array}{l}0.37 \\
0 \cdot 02 \\
0 \cdot 36 \\
0 \cdot 26\end{array}$ & $\begin{array}{l}0.65 \\
0.10 \\
0.01 \\
0.04\end{array}$ \\
\hline
\end{tabular}

* The number of c.f.u. $\mathrm{ml}^{-1}$ at $24 \mathrm{~h}$ was $3 \times 10^{7}$.

the concentration of glucose in the chamber fluid in vitro after the serum-sensitive BS4 (agar) had been growing in it for $24 \mathrm{~h}$. However, the reverse was true for lactate, there being a considerable (60 to $100 \%$ ) reduction in concentration. As in chamber fluid in vivo, acetate concentrations did not change significantly. Of the amino acids, only the concentrations of glutamine and proline were decreased and those of aspartate and alanine increased (Table 4). Addition of asparagine $\left(0 \cdot 11 \mathrm{mmol}^{-1}\right)$ to the chamber fluid produced no significant change except that the concentration of aspartate was further increased.

The decrease in lactate was interesting, but preliminary experiments suggested that it was not solely responsible for the late loss of serum resistance. First, in some experiments, although lactate was metabolized, an appreciable amount $\left(4 \mathrm{mmol} \mathrm{l}^{-1}\right)$ was still present in the chamber fluid when serum resistance was lost. Second, addition of more lactate $(6 \mathrm{mmol}$ $\mathrm{1}^{-1}$ ) at about $12 \mathrm{~h}$ did not prolong the expression of resistance until $24 \mathrm{~h}$.

\section{DISCUSSION}

The failure of the gonococcal population in guinea pig chambers to reach more than about $5 \times 10^{6}$ organisms $\mathrm{ml}^{-1}$ may have been due to anaerobic conditions in the chambers (Rittenberg et al., 1977). The method of measuring redox potential described here may not have been accurate and the results were somewhat variable. However, in comparison with heart blood and caecal contents, the chambers were not anaerobic even when infected, in agreement with the results of Novotny et al. (1977). Nevertheless, when $\mathrm{H}_{2} \mathrm{O}_{2}$ was added to the chambers, both the redox potential and the gonococcal population increased. Hence, whatever substrate was providing the energy requirements, oxygen availability in the chamber may have contributed to the limitation of growth. However, increasing the redox potential did not decrease serum resistance (Table 1).

The $\mathrm{pH}$ of the chambers was slightly alkaline before infection and had fallen only marginally after $24 \mathrm{~h}$ despite the intense inflammatory response which might have been expected to cause acidic conditions (Hays \& Mandell, 1974). This slightly alkaline pH may have had an influence in maintaining serum resistance if the metabolism of the factors responsible were affected by changes in $\mathrm{pH}$, as is the metabolism of glucose (Morse \& Hebeler, 1978).

During infection of normal chambers, serum resistance of the gonococci was expresed during the exponential phase of growth (Table 2) as well as at $24 \mathrm{~h}$. By this time the population had reached the maximum it attains even after days of infection (Veale et al., 1975). The stationary phase might not have been reached at $24 \mathrm{~h}$, because gonococci will have 
been removed by phagocytosis and by migration into the surrounding tissue. However, large numbers of gonococci were not present either in phagocytes or in the surrounding tissue (Veale et al., 1975; Chandler et al., 1976) and therefore it is probable that the growth rate at $24 \mathrm{~h}$ was slow. Thus, in the guinea pig chambers, serum resistance seems to be expressed regardless of growth phase, unlike the greater resistance of exponential phase, egg-grown gonococci (Gibbs \& Roberts, 1975) and the variable serum resistance of other Gram-negative bacteria during different growth phases (Muschel \& Fong, 1977).

Previous investigations (Rittenberg et al., 1977) had raised the possibility that the low glucose concentrations in infected subcutaneous chambers might be responsible for the serum resistance of gonococci in these chambers. However, this appears not to be so. Addition of glucose to the chambers so that the concentration was comparable with that found in the laboratory medium (AG broth) in which chamber-grown organisms became susceptible to serum killing after incubation in vitro (Rittenberg et al., 1977) did not abolish the serum resistance of the chamber-grown organisms or influence their growth (Table 2). Also growth of gonococci in vitro in AG broth of low glucose content did not confer serum resistance. The relatively low counts of gonococci in the chambers (Rittenberg et al., 1977) were not due to low glucose concentrations. Under these conditions gonococci may utilize carbon and energy sources other than glucose; one such substance is lactate (Hebeler \& Morse, 1976). As might have been expected because of glycolysis by the large number of phagocytes $\left(10^{7} \mathrm{ml}^{-1}\right)$ in the inflammatory response, the lactate concentration in the chambers increased during infection (Fig. 1) and this substrate could have been utilized by the gonococci. On the other hand, concentrations of amino acids remained relatively constant during infection, the demand by the relatively small numbers of gonococci $(5 \times$ $\left.10^{6} \mathrm{ml}^{-1}\right)$ and any requirements of the phagocytes being satisfied by homeostatic mechanisms of the guinea pig.

Rittenberg et al. (1977) showed that chamber-derived organisms retained their serum resistance when grown in chamber fluid in vitro but not in AG broth. However, even in chamber fluid the serum resistance was lost after 12 to $24 \mathrm{~h}$ culture. We have shown here that serum-sensitive BS4 (agar) organisms regain their serum resistance after 0.5 to $1 \mathrm{~h} \mathrm{in}$ chamber fluid at $37{ }^{\circ} \mathrm{C}$ and maintain it for about 10 generations when there is a reversion to serum susceptibility after 12 to $18 \mathrm{~h}$ incubation. Adsorption of chamber fluid constituents to the gonococcal surface was not the reason for acquiring serum resistance since treatment of gonococci with chamber fluid at $25^{\circ} \mathrm{C}$ and $4{ }^{\circ} \mathrm{C}$, temperatures at which adsorption but not metabolic modification or multiplication would take place, did not confer serum resistance. Thus, expression of serum resistance may depend on the utilization of specific substrates which are limited in chamber fluid in vitro (when the organisms become susceptible) but are replaced as they are used in vivo. The specific nature of the substrates is indicated by the fact that acquisition of resistance by BS4 (agar) organisms did not occur in the complex medium used by Rittenberg et al. (1977). The situation may be akin to the recent demonstration (Taylor, 1978) of the effect of growth conditions on the serum resistance of strains of Escherichia coli from the urinary tract.

The depletion of lactate, glutamine and proline in chamber fluid in vitro after growth of gonococci for $24 \mathrm{~h}$ (Table 4) does not occur in vivo where serum resistance is maintained. Thus, one or more of these compounds may be involved in maintaining serum resistance, although loss of resistance in vitro does not correspond with complete usage of any one of them (Tables 3 and 4). The most marked effect of gonococcal growth was the decreased concentration of lactate, but addition of more lactate during the late-exponential growth phase of gonococci in chamber fluid in vitro did not prolong expression of serum resistance. However, serum resistance may rely on the correct balance of the three nutrients that appear to be used by gonococci and on other factors not yet recognized; hence further study is required.

The surface components which may account for the phenotypically expressed serum 
resistance of gonococci grown in chamber fluid have not been investigated. Adaptation to growth in guinea pig chambers appears to produce capsule-like structures on gonococci which can be retained during minimal subculture in vitro (Hormaeche et al., 1978; Ward et al., 1978). Ward et al. (1978) reported that chamber-adapted organisms obtained from a parent strain P9 (PS) were resistant to killing by rabbit antibody to lipopolysaccharide and complement in fresh human serum; this resistance (and the capsule-like structure) was maintained after subculture in vitro in a medium described by Swanson (1977) and hence a stable serum-resistant genotype may have been selected by the conditions in guinea pig chambers. The capsular material or possibly the production of $\mathrm{O}$ chains on the lipopolysaccharide of the gonococci (Ward et al., 1978) may have protected these organisms from serum killing. Whether such explanations apply to the phenotypically expressed resistance to human serum described by us is a matter for future research.

Our thanks are due to The Wellcome Trust for a Research Travel Grant (M.G.) and to D. G. Wenham for assistance with gas-liquid chromatography.

\section{REFERENCES}

Broome, J. D. (1961). Evidence that the L-asparaginase activity of guinea pig serum is responsible for its antilymphoma effects. Nature, London 191, $1114-1115$.

Chandler, F. W., Kraus, S. \& Watts, J. C. (1976). Pathological features of experimental gonococcal infection in mice and guinea pigs. Infection and Immunity' 13, 909-914.

GibBs, D. L. \& Roberts, R. B. (1975). The interaction in vitro between human polymorphonuclear leucocytes and Neisseria gonorrhoeae cultivated in the chick embryo. Journal of Experimental Medicine 141, 155-171.

Gutman,, I. \& Wahlefeld, A. W. (1974), L-(+)Lactate. Determination with lactate dehydrogenase and NAD. In Methods of Enzymatic Analysis, 2nd edn, p. 1464. Edited by H. U. Bergmeyer. New York: Academic Press.

HaYs, R. C. \& MANDELl, G. L. (1974). $\mathrm{pO}_{2}, \mathrm{pH}$ and redox potential of experimental abcesses. Proceedings of the Society for Experimental Biology and Medicine 147, 29-30.

Hebeler, B. H. \& Morse, S. A. (1976). Physiology and metabolism of pathogenic Neisseria: tricarboxylic acid cycle activity in Neisseria gonorrhoeae. Journal of Bacteriology 128, 192-201.

Holten, E. (1973). Glutamate dehydrogenases in genus Neisseria. Acta pathologica et microbiologica scandinavica 81, 49-58.

Holten, E. (1976). Radiorespirometric studies in genus Neisseria. 3. The catabolism of pyruvate and acetate. Acta pathologica et microbiologica scandinavica 84, 9-16.

Hormaeche, R. D., Thornley, M. J. \& Glauert, A. M. (1978). Demonstration by light and electron microscopy of capsules on gonococci recently grown in vivo. Journal of General Microbiology 106, 81-91.

McCutchan, J. A., Levine, S. \& Braude, A. I. (1976). Influence of colony type on susceptibility of gonococci to killing by human serum. Journal of Immunology 116, 1652-1655.

Morse, S. A. \& Hebeler, B. H. (1978). Effect of pH on growth and glucose metabolism of Neisseria gonorrhoeae. In Immunobiology of Neisseria gonorrhoeae, pp. 9-17. Edited by G. F. Brooks, E. C. Gotschlich, K. K. Holmes, W. D. Sawyer \& F. E. Young. Washington, D.C.: American Society for Microbiology.

Muschel, L. H. \& Fong, J. S. C. (1977). Serum bactericidal activity and complement. In Biological Amplification Systems in Immunology, pp. 137158. Edited by N. K. Day \& R. A. Good. New York: Plenum.

Novotny, P., Short, J. A., Hughes, M., Miler, J. J., Syrett, C., Turner, W. H., Harris, J. R. W. \& Maclennan, I. P. B. (1977). Studies on the mechanism of pathogenicity of Neisseria gonorrhoeae. Journal of Medical Microbiology 10, 347365.

Penn, C. W., Sen, D., Veale, D. R., Parsons, N. J., SmIth, H. \& WITt, K. (1976). Morphological, biological and antigenic properties of Neisseria gonorrhoeae adapted to growth in guinea-pig subcutaneous chambers. Journal of General Microbiology 97, 35-43.

Penn, C. W., Veale, D. R., Rittenberg, S. C. \& SMITH, H. (1977a). The properties of gonococci in vivo and in vitro: selection and phenotypic change in relation to virulence. In Gonorrhoea: Epidemiology and Pathogenesis, pp. 117-131. Edited by F. A. Skinner, H. Smith \& P.D. Walker. London: Academic Press.

PenN, C. W., Veale, D. R. \& SMith, H. (1977b). Selection from gonococci grown in vitro of a colony type with some virulence properties of organisms adapted in vivo. Journal of General Microbiology 100, 147-158.

Rittenberg, S. C., Penn, C. W., Parsons, N. J., Veale, D. R. \& Smith, H. (1977). Phenotypic changes in the resistance of Neisseria gonorrhoeae to killing by normal human serum. Journal of General Microbiology 103, 69-75.

Schoolnik, G. K., Buchanan, T. M. \& Holmes, K. K. (1976). Gonococci causing disseminated gonococcal infection are more resistant to the bactericidal action of normal human sera. Journal of Clinical Investigation 58, 1163-1173. 
Swanson, J. (1977). Surface components associated with gonococcal cell interactions. In The Gonococcus, pp. 369-402. Edited by R. B. Roberts. New York: John Wiley.

TAYLOR, P.W. (1978). The effect of the growth environment on the serum sensitivity of some urinary Escherichia coli strains. FEMS Microbiology Letters 3, 119-122.

Veale, D. R., Smith, H., Witt, K. A. \& Marshall, R. B. (1975). Differential ability of colonial types of Neisseria gonorrhoeae to produce infection and an inflammatory response in subcutaneous perforated plastic chambers in guinea pigs and rabbits. Journal of Medical Microbiology 8, 325335.
WARD, M. E., WATt, P. J. \& GlynN, A. A. (1970). Gonococci in urethral exudates possess a virulence factor lost on subculture. Nature, London 227, 382-384.

Ward, M. E., Lambden, P. R., Heckels, J. E. \& WATT, P. J. (1978). The surface properties of Neisseria gonorrhoeae: determinants of susceptibility to antibody complement killing. Journal of General Microbiology 108, 205-212.

WERNER, W., REY, H. G. \& WiELINGER, H. (1970). Uber die Eigenschaften eines neuen Chromogens für die Blutzucker-Bestimmung nach der GOD/ POD Methode. Zeitschrift für analytische Chemie 252, 224-228. 